Birgitte Bjønness

Norges miljø- og biovitenskapelige universitet

Astrid Tonette Sinnes

Norges miljø- og biovitenskapelige universitet

DOI: http://dx.doi.org/10.5617/adno.6474

\title{
Hva hemmer og fremmer arbeidet med Utdanning for Bærekraftig Utvikling i videregående skole?
}

\section{Sammendrag}

Læreplanene for grunnopplaringen i Norge er for tiden under revisjon og fornyelse. Fagfornyelsen innebcrer blant annet at bcerekraftig utvikling blir et tverrfaglig og gjennomgående tema $i$ skolen. Satsingen på Utdanning for Bcerekraftig Utvikling (UBU) i skolen er per i dag hovedsakelig preget av enkeltstående prosjekter drevet fram av enkeltlcerere. Vi har i denne studien intervjuet skoleledelse, lcrere, elevråd, driftsleder og skoleeier ved fire videregående skoler for å få fram praksisfeltets stemmer knyttet til hva som hemmer og hva som fremmer arbeidet med UBU i norsk videregående skole. Funn fra studien viser at alle informantene er positive til en satsing på bærekraftig utvikling. Vi finner videre at det utkrystalliserer seg ni sentrale faktorer som påvirker $i$ retning av å hemme eller fremme en helhetlig satsing på UBU. Informantene peker på hverandre når det gjelder å ta initiativ til å utvikle UBU lokalt; dette kan medføre en pulverisering av ansvar så lenge alle «sitter på gjerdet» og venter på at andre skal ta initiativ. En forpliktende satsing på UBU stiller krav til alle aktører og nivåer i skolen. Vi stiller spørsmål om satsingen på bærekraftig utvikling i fagfornyelsen er tilstrekkelig for å utvikle den tverrfaglige forståelsen og handlingskompetansen som er nødvendig for å forberede elevene på å leve bærekraftige liv i framtiden. En forpliktende satsing på UBU krever også at skolen og lererne får tid og rom til å utvikle organisasjonen og leringsmåter lokalt.

Nøkkelord: utdanning for bærekraftig utvikling, fagfornyelsen, videregående skole, hel-skoletilncerming, fokusgruppeintervjuer, aktører i skolen 


\title{
Exploring drivers and challenges for the implementation of Education for Sustainable Development in upper secondary school
}

\begin{abstract}
The national curricula in Norway are currently under review and revision. As part of the revision, sustainable development becomes an interdisciplinary and comprehensive subject in school. There are presently few or no examples of schools that work comprehensively with Education for Sustainable Development (ESD) in Norway. In this study, we have interviewed school management, teachers, student council, operation manager and school owner at four upper secondary schools in order to map what supports and what constrains a holistic effort to ESD in Norwegian upper secondary school. Findings from the study show that all the interviewees are positive to a commitment to sustainable development as part of the new curriculum. Further, we identify nine key factors influencing action as well as resulting from it, in the direction of support or constraint of a holistic effort to ESD. The interviewees point to each other when it comes to taking the initiative to develop ESD locally; this can result in a pulverization of responsibility as long as everyone "sits on the fence" waiting for others to take the initiative. A binding commitment to ESD places demands on all actors and levels at the school. We ask whether the inclusion of sustainable development in the new curriculum is sufficient for developing an interdisciplinary understanding and the action competence that is necessary to prepare the students for living sustainable lives in the future. A commitment to ESD also requires the school and the teachers to have the time and space to develop the organization and learning methods locally.
\end{abstract}

Keywords: Education for Sustainable Development, curriculum reform, upper secondary school, whole-school approach, focus-group interviews, stakeholders in school

\section{Innledning}

Læreplanene for grunnopplæringen i Norge er for tiden under revisjon og fornyelse. I Stortingsmelding nr. 28 Fag - Fordyping - Forståelse: En fornyelse av Kunnskapsløftet, som ligger til grunn for arbeidet med fagfornyelsen, står det at bærekraftig utvikling, folkehelse og livsmestring, samt demokrati og medborgerskap skal bli prioriterte emner i skolen (Kunnskapsdepartementet, 2016, s. 7). Selv om dette i Stortingsmeldingen nå fremmes som noe nytt, har bærekraftig utvikling hatt en plass i norsk skole siden 1974 (Kirke- og undervisningsdepartementet, 1974). Også i den versjonen av Kunnskapsløftet som nå skal fornyes, har 
bærekraftig utvikling hatt en plass, både gjennom den generelle delen av læreplanen sin målsetning om å utdanne miljøbevisste mennesker (Utdanningsdirektoratet, 2011) samt i fagplanene hvor dette temaet har blitt vektlagt i naturfag, samfunnsfag og også til dels i kunst og håndverk og KRLE (Utdanningsdirektoratet, 2018). Når det nå likevel fremmes som et tverrfaglig tema som skal bli prioritert, må det skyldes at den oppmerksomheten temaet har hatt til nå, likevel ikke har ført til en sterk prioritering i den norske skolen.

Sammenlignet med våre skandinaviske naboland finnes det veldig lite forskning på hvorvidt Utdanning for Bærekraftig Utvikling (UBU) har vært prioritert i norsk skole (Sinnes \& Straume, 2017). En evaluering av Den Naturlige Skolesekken (det største UBU-initiativet som gir støtte til prosjekter som arbeider med bærekraftproblematikk i norsk skole) viser at mye av det som har skjedd i norsk skole er enkeltprosjekter, som i liten grad har påvirket skolepraksisen utover enkelte læreres undervisningspraksis i kortere perioder (Sjaastad, Carlsten, Opheim \& Jensen, 2014). Mindre undersøkelser, i all hovedsak utført av masterstudenter, kan også tyde på at bærekraftig utvikling, til tross for en plass i læreplanene, ikke har blitt prioritert tilstrekkelig i den norske skolen. Det er få eksempler på skoler som jobber helhetlig med dette perspektivet (Laumann, 2007; Sundstrøm, 2016), lærere synes det er vanskelig å få til tverrfaglige prosjekter (Koller, 2009; Sundstrøm, 2016), og lærerne opplever selv at de har liten kompetanse i å arbeide med dette temaet (Sundstrøm, 2016). Likeledes viser en internasjonal evaluering av Norges oppfølging av FNs tiår for UBU at det har vært utfordrende å skulle utvide perspektivet fra det naturfaglige, med fokus på miljø, til mer tverrfaglige og integrerte arbeidsmåter og perspektiver, som kjennetegner utdanning for bærekraftig utvikling (Andresen, Høgmo \& Sandås, 2015). En spørring gjort til norske skoleledere i 2011 om hvordan FNs tiår for utdanning for bærekraftig utvikling hadde påvirket deres praksis, svarte bare $9 \%$ at dette initiativet hadde høy prioritet på skolene deres (Vibe, 2012, kap. 7). Denne forståelsen underbygges av Andresen m.fl. (2015) sin artikkel om effekten av FNs tiår for utdanning for bærekraftig utvikling i Norge.

En helhetlig satsing på bærekraftig utvikling i skolen innebærer at elevene får kunnskap om bærekraftproblematikken, men også at de får anledning til å utforske i praksis hva problemene handler om, og at de lærer hvordan de kan bidra til en mer bærekraftig verden (Breiting \& Mogensen, 1999; Hodson, 2014; Sterling, 2001). En læreplananalyse gjennomført av Naturfagsenteret i 2010 (Naturfagsenteret, 2010) viste at læreplanene i Kunnskapsløftet i all hovedsak la opp til en undervisning om bærekraftig utvikling, altså undervisning med vekt på å fremme elevenes teoretiske forståelse av problematikken, oftest innen enkeltfagene. Flere (f.eks. Sinnes \& Eriksen, 2016) peker på at testregimet som har preget store deler av utdanningsdiskursen, har vanskeliggjort en helhetlig vektlegging av bærekraftig utvikling i skolen ved at det fremmer fokus på teoretisk fagkompetanse og fører til et press i en retning av undervisning som fremmer 
læring innen fagene, heller enn holdningsskapende arbeid og tverrfaglig samarbeid.

Alt i alt kan det synes som om læreplanene for Kunnskapsløftet i liten grad har bidratt til å fremme bærekraftig utvikling i den norske skolen. Dette utelukker ikke at enkeltlærere og til dels også enkelte skoler i Norge har klart å arbeide godt med denne tematikken. Den Naturlige Skolesekken har i løpet av de ni årene den har eksistert gitt støtte til 613 prosjekter over hele Norge som har jobbet med bærekraftig utvikling i skolen (Natursekken, 2018). Flere skoler over hele landet har blitt miljøsertifisert gjennom Grønt flagg (Grønt flagg, 2018). FN-sambandet, Naturvernforbundet og andre organisasjoner har vært inne i mange skoler med undervisningsopplegg knyttet til denne tematikken.

I norsk sammenheng finnes det altså lite tidligere forskning på hvordan skoler, og da spesielt videregående skoler, arbeider med UBU. Vi vil derfor gjennom denne artikkelen se på hva informanter fra fire videregående skoler sier virker hemmende og fremmende for sitt arbeid med bærekraftig utvikling per i dag. Selv om disse fire skolene fram til nå har arbeidet ganske ulikt med bærekraftig utvikling, har fokuset i denne artikkelen ikke vært på å beskrive ulikhetene blant skolene, men å lete etter hva som binder de ulike skolene og deres arbeid med å fremme UBU sammen. Gjennom intervjuer av ulike aktører i skolen (skoleeier, rektor, ledelse, driftsleder, lærere og elevråd) har vi identifisert fellestrekk i hva skolene mener fremmer og hemmer en helhetlig tilnærming til UBU i skolen. Med «helhetlig tilnærming til UBU» mener vi et fokus hvor bærekraftperspektivene er integrert i så vel undervisningen som drift og ledelse av skolen, og altså hvordan UBU-fokuset kommer fram i skolens praksis. Følgende forskningsspørsmål driver denne studien: Hva hemmer og hva fremmer en helhetlig satsing på UBU ifølge sentrale informanter i videregående skole?

\section{UBU: fra kunnskap OM til handling FOR en mer bærekraftig verden}

Utdanning for bærekraftig utvikling har blitt beskrevet som en utdanning som både fremmer teoretisk kunnskap om miljø og bærekraft, og som legger opp til en undervisning i miljøet hvor en målsetning er å fremme elevenes kontekstuelle kunnskap knyttet til miljø og bærekraft. Det er også en undervisning hvor ikke bare elevenes teoretiske kunnskap blir utviklet, men også deres evner til å handle for en mer bærekraftig verden (Alsop \& Bencze, 2014; Breiting \& Mogensen, 1999; Hodson, 2014). For å øke elevenes handlingskompetanse har flere pekt på at skolene må drives på en bærekraftig måte, slik at det blir samsvar mellom det elevene lærer og det de opplever. På denne måten vil elevene få oppleve skolen som en aktør for bærekraftig utvikling (Gadotti, 2010; Sterling, 2001; UNESCO, 2014; Wals \& Benavot, 2017). Vi går i det følgende nærmere inn på teorigrunnlaget knyttet til handlingskompetanse, samt litteratur som tar for seg UBU som helhetlig satsing i skolen. 


\section{Handlingskompetanse for bærekraftig utvikling}

Den retningen verdens miljø har gått i gjennom de siste 40 årene, bør utfordre alle deler av samfunnet, også skolen. På tross av økt kunnskap om miljøet og miljøutfordringene både hva gjelder klimagass og annen menneskeskapt påvirkning på verdens klima, artsutryddelse, havforsuring og oppsamling av plastavfall i hav og på land, har vi i liten grad klart å endre handlingene våre i en retning som minsker disse problemene. Det at kunnskaper ikke nødvendigvis fører til endrede holdninger og handlinger, ble ifølge Burgess, Harrison og Filius (1998) teoretisk beskrevet allerede på 70-tallet. Likevel har ideen om at økte kunnskaper bidrar til å endre handlingsmønster (såkalt «knowledge deficit model») ifølge Burgess m.fl. fått prege skoler og også frivillige organisasjoners arbeid med UBU fram til i dag. Som læreplananalysen gjennomført av Naturfagsenteret (2010) viste, har også Kunnskapsløftet i stor grad lagt opp til en teoretisk behandling av temaet bærekraftig utvikling.

Forskere i Danmark har i lang tid arbeidet med å utvikle forståelse for hvordan elevers handlingskompetanse (action competence) kan utvikles gjennom skolen (Breiting \& Mogensen, 1999; Jensen \& Schnack, 1997; Mogensen \& Schnack, 2010). Når kompetansen for å handle miljøvennlig skal beskrives, skiller Jensen (2002) mellom det han kaller "pro-environmental behaviour» og «actioncompetence». I følge Jensen kan pro-environmental behaviour fremmes hvis ytre faktorer blir endret (for eksempel at det blir billigere å ta toget), uten at det har noe å gjøre med at folk har blitt mer miljøbevisste. I stedet for å fremme en ren "pro-environmental behaviour», argumenterer Jensen for å utvikle elevenes handlingskompetanse, hvor deres kognitive refleksjon knyttet til de handlingene de gjør får en større plass. Alsop og Bencze (2014) skriver i boken "Activist Science and Technology Education» om hvordan kunnskap om et tema forplikter aktørene til handling. Dersom en skole skal lære elevene om et problem, stiller dette også krav til at skolen gjør en innsats for å ta tak i og forsøke å løse problemet.

\section{UBU som helhetlig satsing i skolen}

For å fremme elevenes handlingskompetanse for bærekraftig utvikling kan det altså synes som det er viktig å jobbe med alle deler av elevenes kompetanse både den teoretiske, den holdningsmessige og den handlingsorienterte - hvor alle deler ses på som viktige. I en slik tilnærming finner vi bærekraftig utvikling i skolen som «lived as well as taught» (McKeown \& Hopkins, 2007, s. 22). Dette helhetlige perspektivet er vel etablert i UBU-litteraturen (Gadotti, 2010; Scott, 2013; Sterling, 2001) og også i UNESCOs arbeid med å fremme UBU internasjonalt (UNESCO, 2014). I tillegg til arbeidet med å utvikle undervisning og læring, krever hel-skoletilnærmingen en omarbeiding av skolens virksomhet og miljøarbeid (for eksempel energisparing, grønn skolekantine og resirkulering av søppel), samt fokus på demokratisk deltakelse ved skolen og i samfunnet (Wals \& Benavot, 2017). Implementering av UBU i skolens struktur og rutiner er ifølge 
Sterling (2001) en måte å transformere utdanningen på gjennom å gjøre den mer relevant for samfunnets behov.

Skoleutvikling er sentralt for en helhetlig satsing på UBU. Å arbeide med de ulike skolenivåene i sammenheng blir ansett som en indikator på hel-skoletilnærming (Mogren, Gericke \& Scherp, 2018; Scott, 2013; UNESCO, 2014). Leo og Wickenberg $(2013,2015)$ har studert implementering av UBU i tre videregående skoler i Sverige. Funn fra den svenske studien viser at de nasjonale læreplanene skapte forventinger til lærere og ledelse i skolen. Rektorene var opptatt av å iverksette målene i læreplanen, men også av å promotere skolene ved å benytte UBU som profil. Studien viser også at ildsjeler blant lærerne var viktig for å lykkes med implementering av UBU lokalt. I følge Leo og Wickenberg (2013) indikerer studien deres at profesjonelle normer for endring i retning av helskoletilnærming for UBU trer i kraft når rektorer og lærere erfarer forventninger fra hverandre, elever og styringsdokumenter. Likeledes fant Mogren og kollegaer (2018) i en studie av åtte UBU-skoler i Sverige at alle nivåer i skolen, slik som elever, lærere, ledelse, foreldre og samfunnet, er viktige for å støtte UBU-handling og progresjon. Studien viser at hel-skoletilnærmingen blant annet er kjennetegnet av at lærerne har en holistisk tilnærming til planlegging, gjennomføring og evaluering av undervisningen, og at de har en tverrfaglig UBU-strategi. Videre viser studien at en «bottom-up»-prosess som tar utgangspunkt i erfaringer og praksiser ved den enkelte skole, er nødvendig for en best mulig forankring i skolen som organisasjon.

\section{Datamaterialet}

Datamaterialet i artikkelen stammer fra tilsammen tolv fokusgruppeintervjuer ved fire videregående skoler på det sentrale Østlandet. Vi har benyttet følgende pseudonymer på skolene: Anker vgs., Bjørk vgs., Delta vgs. og Kvale vgs. Tre av skolene er kombinerte skoler med hovedvekt på allmennfag, mens én av skolene er en naturbruksskole med hovedvekt på yrkesfag. Intervjuene ble foretatt i juni 2017 ved hver enkelt skole. Følgende grupper ble intervjuet: ledelse og lærere ved alle de fire skolene, elever i elevrådet ved to av skolene, driftsleder ved én av skolene, samt skoleeier (Fylkeskommunen) ved pedagogisk utviklingsleder og regionsdirektør. Alle informantene i studien er anonymisert. Intervjuguiden var rettet mot å belyse dagens situasjon knyttet til hva de ulike informantene opplevde som hemmende og fremmende i arbeid med bærekraftig utvikling ved den enkelte skole. Vi valgte semi-strukturerte intervjuer (Kvale, 2008) slik at informantene kunne snakke relativt fritt og relatere til sin egen praksis og erfaring. Ledelsen ved skolene valgte ut informanter i følgende grupperinger: lærere, elevråd, ledelse og driftsleder. Det ble foretatt pragmatiske valg ut fra hvem som kunne stille i slutten av vårsemesteret. Intervjuguiden ble sendt til ledelsen på forhånd og formidlet videre til informantene. Alle informantene har levert skriftlig samtykke til studien. 
Intervjuene ble foretatt av forfatterne som begge arbeider som lærerutdannere og forskere innenfor naturfagdidaktikk. Fokusgruppeintervjuene varte mellom tretti minutter og en time.

\section{Dataanalyse}

I denne artikkelen ønsker vi å undersøke hva sentrale informanter i praksisfeltet framhever som fremmer eller hemmer en helhetlig satsing på UBU i videregående skole. Studien er begrenset til fire videregående skoler, men ved å identifisere fellestrekk i hva informanter i skolene peker på som sentrale faktorer for en helhetlig UBU-satsing, kan analysen likevel bidra til å gi et grunnlag for å diskutere muligheter og begrensninger for utvikling av UBU i videregående skoler i Norge.

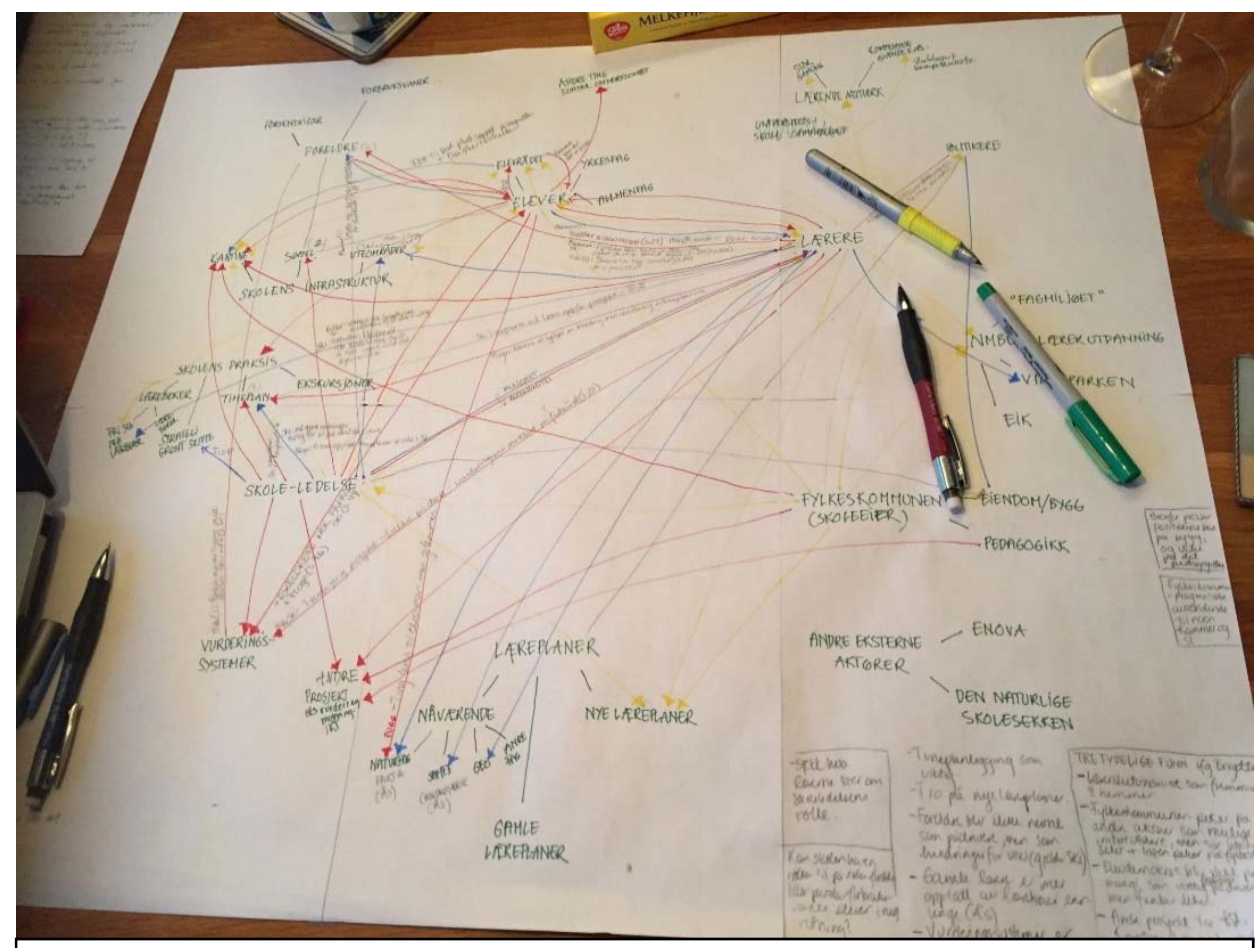

Figur 1. Identifisering av ulike faktorer knyttet til hva som hemmer eller fremmer en helhetlig satsing på UBU i skolen.

Vi benyttet først en tematisk analyse for å sortere datamaterialet (Braun \& Clarke, 2006); dette innebar utforsking av de transkriberte tekstene fra fokusgruppeintervjuene for å finne mønstre av mening knyttet til forskningsspørsmålet. Tilnærmingen kan beskrives som abduktiv gjennom at forfatterne vekslet mellom induktiv og teoridrevet koding preget av vår forskningsinteresse innenfor UBU. Analysearbeidet foregikk iterativt gjennom at begge forfatterne leste gjennom transkripsjonene av fokusgruppeintervjuene og gjorde oss notater knyttet til temaer vi oppfattet at representerte noe viktig i relasjon til forskningsspørsmålet 
eller hadde framtredende plass i datamaterialet. Neste fase i analysearbeidet var å identifisere ulike faktorer i skolen og hvordan de påvirker hverandre i satsingen på UBU. Vi tegnet et fysisk kart over faktorene som ble nevnt i fokusgruppeintervjuene (for eksempel: lærere, elevrådet, foreldre, kantine, lærebøker, ny læreplan); disse kunne være både innenfor og utenfor skolen. Se figur 1 . Vi tegnet deretter inn linjer mellom faktorene, der antallet reflekterte hvor ofte de enkelte ble nevnt av informantene, og fargekoding som viste om forholdet ble vurdert som fremmende, hemmende eller begge deler for UBU. Vi fikk på denne måten et bilde av hvilke faktorer som er sentrale i satsingen på UBU i de fire videregående skolene i studien, og knyttet dette til temaer som kom fram i den tematiske analysen.

\section{Resultater}

Gjennom analysen av datamaterialet identifiserte vi ni hovedfaktorer som alle enten hemmer, fremmer, eller både hemmer og fremmer arbeidet med en helhetlig satsing på UBU i skolen: de nye læreplanene, skoleledelse, eksterne aktører, lærere, elevrådet, skoleeier (fylkeskommunen), søppelhåndtering og kantine, vurderingspraksis og foreldre. Vi presenterer i det følgende først en oversikt over de ni identifiserte hovedfaktorene (tabell 1). Deretter tar vi for oss faktorene enkeltvis for å utdype hvordan de hemmer og/eller fremmer arbeidet med en helhetlig UBU-satsing.

Tabell 1. Hovedfaktorer i de fire videregående skolene i studien som alle fremmer og/eller hemmer arbeidet med UBU.

\begin{tabular}{lcc}
\hline Faktor & Fremmer & Hemmer \\
\hline De nye læreplanene & $\mathrm{X}$ & \\
Skoleledelse & $\mathrm{X}$ & $\mathrm{X}$ \\
Eksterne aktører & $\mathrm{X}$ & $\mathrm{X}$ \\
Lærere & $\mathrm{X}$ & $\mathrm{X}$ \\
Elevrådet & $\mathrm{X}$ & $\mathrm{X}$ \\
Skoleeier & $\mathrm{X}$ & $\mathrm{X}$ \\
Søppelhåndtering og kantine & $\mathrm{X}$ & $\mathrm{X}$ \\
Vurderingspraksis & & $\mathrm{X}$ \\
Foreldre & & $\mathrm{X}$ \\
\hline
\end{tabular}

\section{De nye læreplanene}

En faktor som ble pekt på som sentral for å fremme UBU-fokuset i videregående skoler, var de nye læreplanene. Skoleeier uttaler seg positivt om innføring av tre tverrfaglige tema i fornyelsen av læreplanverket, og hevder at fokus på UBU gir muligheter i skolen. Pedagogisk leder hos skoleeier uttaler følgende om innføring av nye læreplaner:

Jeg syns det ligger mye i forslaget i den nye læreplanen der man legger vekt på nettopp tverrfaglighet, bærekraftig utvikling, kritisk tenkning, refleksjon rundt seg, styrke 
naturfagene, se de sammenhengene og hvordan omgivelsene påvirker oss når det gjelder ulike typer stoffer og samspillet med naturen generelt.

Geir (pedagogisk leder, skoleeier)

Pedagogisk leder hos skoleeier uttaler seg positivt om bærekraftig utvikling og ser tematikken i en tverrfaglig sammenheng. Ledelsene ved skolene er også opptatt av de nye læreplanenes satsing på tverrfaglighet innenfor UBU; uttalelsen til en av rektorene i studien illustrerer dette:

I de nye læreplanene er det viktig at det inngår noen kompetansemål som setter krav til grundighet og forståelse i større grad enn å si at det skal være miljøbevisst. (...) Jeg klarer da ikke heller å se dette faglig, uten at lærerplanen har noen krav om integrering mellom fag da.

Inger (rektor, Anker vgs.)

Ledelse og lærere ved alle skolene er positive til en utvikling i retning av mer tverrfaglig arbeid, men de legger også vekt på at dette har vært vanskelig å få til fordi det tradisjonelt er mye faglig silotenkning som preger skolekulturen på videregående trinn. Ledelse og lærere er opptatt av at nye læreplaners pålegg om tverrfaglighet kan være et steg i retning av å måtte utvikle nye samarbeidsformer og didaktiske tilnærminger i undervisningen.

\section{Skoleledelse}

Skoleledelsen blir av lærere og skoleeier pekt på som viktig for å få til et UBUfokus i skolen. Ledelsene ved skolene ser imidlertid på sin rolle mer som tilretteleggere enn som initiativtakere. For eksempel er de opptatt av timeplanleggingen på skolene som en viktig faktor for å få på plass en UBU-satsing lokalt. Medlemmer i ledergruppene ved skolene snakker også om at det å innføre tverrfaglige UBU-prosjekter vil kreve mer arbeid spesielt knyttet til timeplanlegging, men at det er noe de er opptatt av å gjøre.

Det viktigste vi gjør for lærerne våre er å tilrettelegge slik at lærerne får rom og tid til å samarbeide om disse prosjektene og at vi passer på at de lærerne som virkelig ønsker det er de som går inn i for eksempel UBU-prosjektet da. Så det er klart at tilretteleggingsbiten må jo vi stå for. Også er det en økonomisk bit som følger med også. Men selve den driven er det jo ofte lærerne selv som ønsker og driver fram da.

Elise (avdelingsleder, Anker vgs.)

En av avdelingslederne ved Anker vgs. legger også vekt på at skoleledelsen må ta ansvar for å støtte lærerne i hele prosjektet, også når det gjelder å informere foreldre og foresatte ved større tverrfaglige prosjekter:

Så tror jeg når foreldrene kommer på døra, når vi har denne typen prosjekter (tverrfaglige UBU-prosjekter), så må vi gi rom til å prøve og feile også. Og da må vi støtte de lærerne og hele prosjektet. Og det er også en lederoppgave tenker jeg. Vi må støtte dem, vi må forklare det utad. Legitimere det sånn at de har oss i ryggen. Det er kjempeviktig.

Berit (avdelingsleder, Anker vgs.) 
Til tross for at ledergruppene er opptatt av å tilrettelegge for tverrfaglige prosjekter, opplever lærerne at UBU-prosjektene krever mye arbeid og at ledelsen i liten grad har tilrettelagt med ekstra tidsressurs. En av lærerne ved Bjørk videregående skole uttaler følgende i forbindelse med en samtale om mulige tverrfaglige prosjekter ved skolen:

Fine intensjoner og sånt, men det er mye som skal til og vi har undervisning av pensum og $(\ldots)$.

Daniel (lærer, Bjørk vgs.)

Ledelsene ved alle de fire videregående skolene i studien ser på det å satse på UBU som en mulighet for profilering av skolen. I det ligger det at dette er noe særegent som ikke skjer på andre skoler og som kan brukes til å markedsføre skolen.

Perspektivet vårt er jo også at vi skal ha en skole som overlever i konkurranse med andre skoler, men vi skal lage en tydelig profil på hvem vi er. Det blir viktig da, at elever som bor langs jernbanelinja velger oss i stedet for å velge de som ligger mer sentralt. Så tanken er jo at vi skal lage et konsept her som gjør oss spennende og nytenkende.

Vilde (rektor, Bjørk vgs.)

Ledelsene ved skolene ser på sin rolle som tilretteleggere for UBU, og at det er lærerne som må initiere og ta ansvar for UBU-prosjekter i undervisningen. Et slikt perspektiv kan virke hemmende fordi det krever mye av ildsjeler blant lærerne og samtidig fremmende fordi lærere er opptatt av å beholde sin autonomi og profesjonalitet i yrkesutøvelsen. Lærerne peker på behov for at ledelsen legger til rette for at de kan arbeide i tverrfaglige grupper for å få til UBU-prosjekter, og de ønsker en ledelse som er tydelig på hvem som har ansvar. Ledelsene ved skolene ser på UBU som spennende og attraktivt for ungdommer. De ønsker derfor å benytte UBU-satsingen til profilering for å lokke elever til skolen. Samtidig er det tydelige signaler fra ledelsen ved alle skolene at UBU er viktig for å forberede unge mennesker på en verden i endring og at skolen har en viktig rolle som samfunnsaktør.

\section{Eksterne aktører}

Alle skolene har samarbeid med eksterne aktører som bidragsytere til UBU. De eksterne aktørene arbeider inn mot skolene for å fremme bærekraftig utvikling. De eksterne aktørene som blir nevnt er: Den Naturlige Skolesekken, ENOVA (organisasjon som eies av Klima- og miljødepartementet som arbeider for Norges omstilling til lavutslippssamfunn), Ungt Entreprenørskap, og UEAT (årlig ungdomskonferanse som handler om mat, miljø og bærekraft, arrangert av Vitenparken). I tillegg nevnes også samarbeid med Norges miljø- og biovitenskapelige universitet (NMBU) som ekstern aktør.

Ved Delta vgs. og Anker vgs. har elevene i første klasse på studiespesialisering i flere år vært deltakere på innovasjonscamp i regi av ENOVA og Ungt 
entreprenørskap. Ledelsen ved Delta vgs. er opptatt av mulighetene en slik «happening» som innovasjonscampen gir gjennom å inspirere elevene, og til faglig forberedelse og samarbeid med flere fag. Ledelsen ved Anker vgs. er mer kritisk til denne type «happening» i skolen, og legger vekt på at det fungerer mer som et avbrekk i skolehverdagen:

For vi er jo enige om at den happeningen (ENOVA innovasjonscampen) kan være allright, men du vet de får ikke gått noe i dybden på en slik happening. De har det allright og de tenker noen tanker, men det er ikke en fordøyd ting. Så det er kanskje et lite sånn avbrekk og hvor de gjør noe som er viktig i dagens samfunn, det tenker jeg.

Berit (avdelingsleder, Anker vgs.)

Ledere ved skolene mener at undervisningsopplegg som utvikles på skolen i samarbeid mellom lærere er potensielt mest vellykka og varig. Eksterne aktører som Vitenparken (UEAT), Ungt entreprenørskap og ENOVA anses mer som «happenings». Eksterne prosjekter pekes på blant en del av lærerne som problematiske i skolehverdagen fordi elevene mister tid til ordinær undervisning.

\section{Lærere}

Ledelsene ved de fire videregående skolene peker på betydningen av at lærerne får beholde sin autonomi knyttet til planlegging, gjennomføring og vurdering av undervisningen. Ledelsen ønsker å tilrettelegge, men ikke legge for mange føringer for hvordan lærerne skal implementere utdanning for bærekraftig utvikling i sin undervisning. De er opptatt av at lærernes entusiasme skal få være drivende for deres UBU-engasjement $\mathrm{i}$ likhet med engasjement $\mathrm{i}$ andre utviklingsprosjekter i skolen. Dette kan illustreres ved avdelingsleder Hanne ved Delta vgs. sin uttalelse:

Det er slike prosjekter (tverrfaglige prosjekter i fagteam) som krever at lærerne føler at de eier det, ikke at det er meg eller Tina. Vi har ikke tid til å følge opp lærerne. Vi kan sette dem sammen og sette dem i gang. Og så må de ønske å drive det litt sjøl for at det skal bli vellykka.

Hanne (avdelingsleder, Delta vgs.)

Lærerne er også opptatt av autonomi, men mener at ledelsen må legge til rette for UBU-prosjekter slik at ikke enkeltlærere blir stående med ansvaret. En av lærerne ved Bjørk vgs. uttaler følgende i forbindelse med en samtale om tverrfaglige prosjekter ved skolen: «Hvem skal drifte og drive det, det må jo være noen ildsjeler da.» Lærerne ved de fire skolene trekker fram to sentrale perspektiver som kan virke hemmende på UBU i praksis, det ene er mangel på spillerom og tid til å arbeide med tid- og ressurskrevende UBU-prosjekter slik at det ikke bare faller på ildsjeler, og det andre perspektivet er at tverrfaglige prosjekter gjør at lærere mister tid til det som lærerne kaller ordinær undervisning.

Det kan altså se ut til at rektors og øvrig ledelse sitt ønske om å verne lærernes autonomi i praksis kan virke både fremmende og hemmende for å oppnå et økt fokus på bærekraftig utvikling i skolen. På den ene siden vil lærere som ønsker å 
ha dette fokuset, få frihet til å gjennomføre prosjekter med sine elever. På den annen side vil lærere som ikke ønsker å fokusere på dette, også få muligheten til å la det være. Ledelsene ved skolene er opptatt av timeplanleggingen på skolene som en viktig faktor for å få på plass en UBU-satsing, men at «driven» for disse prosjektene ofte kommer fra lærerne.

\section{Elevrådet}

Elevrådet blir i denne studien pekt på av skoleledelse, skoleeier og lærere som mulige initiativtakere for å få til en økt UBU-satsing i skolen. Elevrådet selv er også opptatt av at de kan og ønsker å spille en rolle, men de peker på en del hindringer for dette slik som elevrådet fungerer per i dag.

I samtale med to elevrådsledere og tillitselever ved to av skolene kommer det fram at det er vanskelig å få medelever engasjert i elevrådsarbeid og gjennomføring av tiltak. Elevrådsleder ved Anker vgs. mener at det er vanskelig for elevrådet å være en pådriver for UBU i skolen.

Det hadde vært mulig å få til noe. Vi har for eksempel lagt merke til at elevrådet har mye kraft når vi først prøver å sette i gang, men det er det at man mangler engasjement. Det kommer ikke mye ideer. Det kommer ikke 'dette har vi lyst til å gjøre’. Salen er veldig stille når vi har møter.

Sindre (tillitselev, Anker vgs.)

Den pedagogiske ledelsen ved Delta vgs. er også inne på at det ikke nødvendigvis er elevene som blir valgt inn i elevrådet som er mest opptatt av skoleutvikling, og at dette virker hemmende for å få gjennomført endringer knyttet til utviklingsprosjekter i skolen.

Jeg har inntrykk av at de som sitter i elevrådet blir valgt inn fordi de er de populære, men det er ikke nødvendigvis at de sitter med, altså har den riktige holdningen de heller, og da er det vanskelig å få solgt inn det du vil hvis den som sitter i elevrådet ikke er (...).

Tina (avdelingsleder, Delta vgs.)

Det kan også synes som om selve prosessen med å få gjennomført tiltak på skolen kan være krevende. En av elevrådslederne forteller at hun har fått lite opplæring i elevdemokrati og hvordan det fungerer.

Skoleeier og skolelederne framhever elevdemokratiets betydning som drivkraft for å få til endringer i skolen. Det kan likevel se ut som om elevrådene ved skolene opplever at de har liten innflytelse gjennom at det er vanskelig å få engasjert medelever for utviklingsprosjekter i skolen. Likeledes kan det være at måten og tidspunktet elevrådet blir valgt på, samt mangel på opplæring av elevrådet i elevdemokrati i praksis, kan være hindringer i prosessen med å få engasjert elevene i utvikling av egen skole.

\section{Skoleeier}

Skoleeier blir av flere pekt på som en sentral aktør for å få til en helhetlig vektlegging på bærekraftig utvikling i skolen. Skoleeier ser imidlertid på seg selv 
som tilrettelegger, og hevder at initiativet for UBU må komme fra andre aktører, og de nevner blant annet skoleledelse, lærere, elever, politikere og universitetet. Skoleeier er opptatt av å «legge til rette» for andres initiativ når det gjelder UBU i skolen. Samtidig uttaler de at de på andre områder har rolle som pådriver. Regionsdirektørens uttalelse illustrerer dette:

Dette området (UBU) kommer ikke fra oss for å si det sånn, da kommer det fra skolen. Men andre prosjekter tror jeg kommer tidvis like mye fra oss som fra enkeltskoler. Og satsingsområder vi har hatt den siste tiden er mer tverrgående som VFL [Vurdering For Læring] og IKT i læring. Altså mer grunnleggende ferdigheter er sentralt her.

Kari (regionsdirektør, skoleeier)

Sitatet kan tyde på at skoleeier per i dag anser UBU som mindre sentral enn andre satsinger i skolen. De uttaler også at det kan bli aktuelt at de tar mer initiativ for å fremme dette fokuset hvis dette blir et større satsingsområde i framtiden.

Ja, du kommer ikke utenom å bruke utdanning på en måte, men om vi skal være en pådriver eller om det er opp til lærerens profesjon og sitt fag, det er jo en annen diskusjon.

Kari (regionsdirektør, skoleeier)

Det ser ut til at eksterne satsingsprosjekter i skolen, slike som «Vurdering for læring» og «IKT i læring», vurderes som mer sentrale for skoleeiers involvering, og dermed kan anses som konkurrenter for skoleeiers innsats for at skolene kan arbeide helhetlig med UBU. Dette pekes på av både skoleledelse, lærere og skoleeier. I fylket er det kun én skole som er miljøsertifisert. På spørsmål om hvorfor det ikke arbeides mer mot dette, svarer skoleeier at det dreier seg om prioritering og at for eksempel det å styrke pedagogisk ledelse er mer aktuelt for hele skolen. Skoleeier er opptatt av skolen og lærernes autonomi, og at dette dermed er noe de kan legge til rette for, men ikke pålegge skolene å gjennomføre, med mindre det kommer et politisk vedtak om at UBU skal være et fokus i skolen. Skoleeier anser heller ikke UBU som et satsingsområde som angår hele skolen.

\section{Søppelhåndtering og kantine}

Det er ved alle skolene et tydelig ønske om miljøfokus knyttet til søppelhåndtering og kantine. Både elever, lærere, ledelse, driftsleder og skoleeier er opptatt av dette som konkrete tiltak for å utvikle skolen i en mer bærekraftig retning og som holdningsskapende tiltak.

For å få et bevisst forhold til det man gjør, det tror jeg er viktig at skolen kan bidra med. Det er vel også det at, jeg tror det at, holdningsbiten er det viktigste oppi det.

Jens (avdelingsleder, Kvale vgs.)

Det er helt klart at du kan påvirkes gjennom hva som er mulig å gjøre på skolen (...) ved at du blir vant til et levemønster, en måte å agere på, så vil jo det endre hvordan du gjør det når du kommer hjem også.

Espen (driftsleder, Anker vgs.) 
Det er stor tro blant ledelse og lærere knyttet til mulighetene skolekantina gir for økt miljøbevissthet og handling. Rektor ved Anker vgs. foreslår at kantina kan være en arena for å utforske bærekraftighet knyttet til mat og selve drifta av kantina.

Så hvis man tenker mat ... hvordan plukker vi salat i kantina, bruker vi plastbeger med masse volum? Vi kunne brukt kantina og mat. Lett å gjøre forsøk, forske i nærområdet bare på det.

Inger (rektor, Anker vgs.)

Rektor ved Bjørk vgs. ser det problematiske i at elevene har prosjekter om matsvinn, men at egen skolekantine er en «blind spot». Skoleeier peker på at halvparten av kantinene er «outsourcet» og presiserer at de mister styringslinjen som de ellers har overfor kantinedriften. Private kantiner har et annet profitthensyn enn skoledrevne kantiner, og dette virker ifølge skoleeier og skoleledelse hemmende på muligheter for å arbeide for en grønnere og sunnere kantine.

Ledelsene ved de fire skolene er alle opptatt av hvordan skolen kan gå foran som et godt eksempel og være med på å påvirke elevenes holdninger til kildesortering og mat som kan lede til endrede handlinger. De er opptatt av at det ikke er nok med skoleprosjekter om mat, men at også skolens drift må gjenspeile et fokus på mat og matsvinn. Ledelsene ved skolene peker også på at elevene gjennom elevrådet har vist engasjement for å få en grønnere kantine eller kildesortering av søppel. Det er likevel en relativt stor oppmerksomhet blant ledelsen og driftsleder knyttet til at det er vanskelig å få til kildesortering og grønn kantine i praksis.

\section{Vurderingspraksis i skolen}

Elever, lærere, ledelse og foreldre er alle opptatt av vurderingspraksis som hemmende for en satsing på UBU i skolen. Elevene forteller at det er et stort karakterpress for å komme inn på de studiene de ønsker etter videregående skole.

(...) man får høre at man kan bli hva som helst og 'nå skal jeg bli lege’ og da må jeg fokusere bare på det og så går alt annet vekk, og da lærerne kommer til deg og skal presse på litt bærekraftig utvikling, så blir det 'å nei, det kommer til å forstyrre meg med at jeg skal bli lege'.

Petter (elev, Anker vgs.)

Elevene forteller om en situasjon der karakterer er svært viktige for deres framtid, dette er også ledelsene ved skolene opptatt av.

Ja og nå når det er så høyt snitt for å komme inn, merker vi at de er veldig stresset for karakter og veldig opptatt av det tallet, nesten mer enn hva det faktisk sier om deg da.

Det er en veldig uheldig utvikling synes jeg.

Hanne (avdelingsleder, Delta vgs.)

Lærere, ledelse og elevrådene forteller at UBU-prosjekter ses på som noe som kommer i tillegg til såkalt ordinær undervisning, og som ikke «teller» inn i 
vurderingen av elevene. Elevene forteller om en kultur i skolen som går på å pugge fagstoffet til prøver og at det fører til at innsatsen blir lavere i tverrfaglige prosjekter som har mindre vekt på vurdering enn vurderingssituasjoner i enkeltfag. Dette kan ses i sammenheng med at lærere og ledelse forteller at vurdering i tverrfaglige prosjekter er vanskelig å gjennomføre i praksis.

\section{Foreldre}

Skoleledelsen, elevene og lærerne ved to av skolene har erfaring med at foreldrene er bekymret for faglig progresjon og elevens karakterer ved tverrfaglige prosjekter. Elevene forteller også om stort karakterpress hjemmefra.

(...) og de her er litt overambisiøse vil jeg si. Barna vil ha 6 og gjøre det veldig bra og komme inn på kjempefine studier, men foreldrene bak er enda hardere, det er et kjempepress på elevene.

Sissel (avdelingsleder, Anker vgs.)

Ledelse og elever ved Anker vgs. og en lærer fra Bjørk vgs. rapporterer om foreldre som ikke kildesorterer og som kjører elevene unødvendig mye til skolen og som ikke nødvendigvis vil følge opp et fokus på bærekraftig utvikling. Ifølge Lena, lærer ved Bjørk vgs., er det utfordrende at foreldre ikke følger opp handlinger knyttet til bærekraftig utvikling; som lærere ser de behovet for å få foreldre på banen.

Det pekes på at foreldrene kan hemme en satsing på UBU fordi de ikke ser betydningen av UBU som en del av skolens ansvar og er mer opptatt av at barna skal prestere i enkeltfag. Skoleledelsen ved Anker vgs. ser muligheter for å øke foreldres og foresattes innsikt i og forståelse for tverrfaglige UBU-prosjekter gjennom at skoleledelsen tar ansvar for å informere om slike prosjekter.

\section{Diskusjon og implikasjoner}

I denne kvalitative studien ønsker vi å få fram praksisfeltets stemmer knyttet til hva som oppleves som hemmende og fremmende for en helhetlig satsing på utdanning for bærekraftig utvikling i videregående skole i Norge.

Det utkrystalliseres ni hovedfaktorer når det gjelder arbeidet med UBU i norsk videregående skole. Disse faktorene påvirker i retning av å fremme eller hemme en helhetlig satsing på UBU. Det er kun de nye læreplanene som blir pekt på av alle som en positiv faktor for å fremme UBU i skolen. Vi finner at vurderingspraksis og foreldre blir pekt på som faktorer som i all hovedsak virker hemmende på et økt fokus på UBU. Videre viser analysene at de fleste faktorene potensielt kan virke både fremmende og hemmende for en satsing på UBU: skoleeier, ledelse, lærere, elevrådet, eksterne aktører, samt søppelhåndtering og kantine blir nevnt både som positive faktorer og som hindringer for en helhetlig 
satsing på UBU. Vi drøfter i det følgende hva disse funnene kan bety for utvikling av UBU i norsk videregående skole.

Vi finner at utdanning for bærekraftig utvikling (Gadotti, 2010; Scott, 2013; Sterling, 2001; Wals \& Benavot, 2017) har lite fokus i de fire skolene. Handlingsperspektivet på bærekraftig utvikling ser ut til å være frikoblet fra det teoretiske fokuset i skolen. Dette kan vanskeliggjøre muligheten til å utvikle elevenes handlingskompetanse (Breiting \& Mogensen, 1999; Jensen \& Schnack, 1997; Olsson, Gericke \& Chang Rundgren, 2016).

Ledelsene ved de fire videregående skolene anerkjenner at de har en viktig rolle for å tilrettelegge og gi legitimitet til tverrfaglige prosjekter. Samtidig er de opptatt av å opprettholde lærerens autonomi og går dermed i liten grad inn og strukturerer timeplanene slik at det kan legges til rette for tverrfaglighet. Dette kan være problematisk i den forstand at det opprettholder et system som gir enkeltlærere spillerom, men der skolen som helhet ikke foretar nødvendige endringer. Studier fra svensk skole viser at ildsjeler blant lærere er viktige for å lykkes med implementering av UBU, men at en hel-skoletilnærming til UBU er avhengig av at alle individer og nivåer i skolen drar i samme retning (Leo \& Wickenberg, 2013, 2015; Mogren, Gericke \& Scherp, 2018; Olsson, Gericke \& Chang Rundgren, 2016). Vår studie viser at lærerne ikke opplever at de får den nødvendige støtten de trenger fra ledelsen, og at mye faller på enkeltlærere som blir stående med ansvaret for mer enkeltstående UBU-prosjekter.

Elevrådet blir pekt på av både ledelsene og skoleeier som en mulig pådriver for et mer praktisk og helhetlig UBU-fokus på skolene. Både skoleeier, lærere, driftsleder og ledelse sier at dersom initiativene om å få til en mer praktisk vektlegging av bærekraft på skolen hadde kommet fra elevene, ville det ha blitt tatt tak i. Ledelsen peker for eksempel på betydningen av at elevrådet viser engasjement for å få en grønnere kantine eller kildesortering av søppel. Det er likevel et stort fokus blant ledelsen og driftsleder knyttet til at det er vanskelig å få til kildesortering og grønn kantine i praksis. Det kan tyde på at elevdemokratiet blir en hvilepute for ledelsen for å unngå å ta dette på alvor. Intervjuene med elevrådsrepresentanter fra skolene viser imidlertid at elevdemokratiet i liten grad fungerer som en pådriver for miljøsaker på skolen. Elevrådsrepresentantene opplever også at de i liten grad får opplæring i hvilke muligheter de har for å påvirke skolen. Her kan det igjen trekkes tråder til den frikoblingen som synes å være til stede mellom teori og praksis i skolen. Man lærer om demokrati ut fra et teoretisk perspektiv, men det gis i liten grad konkret opplæring i demokratiske beslutningsprosesser og elevmedvirkning, noe som ses på som en sentral del av en helhetlig satsing på UBU (Wals \& Benavot, 2017; Sterling, 2001). Ingen av skolene forteller om samarbeid med private organisasjoner eller kommunen om reelle og dagsaktuelle prosjekter innenfor bærekraftig utvikling. Det kan virke som om det er et stort og ubrukt potensial som kan videreutvikles når demokrati og demokratiforståelse i de nye læreplanene skal inn som et eget tverrgående tema. 
Alle skolene som er med i denne studien, har på ulike vis deltatt i eksterne skoleprosjekter, slike som ENOVA og UEAT, som fokuserer på bærekraftig utvikling. Samtlige vi har intervjuet ser på disse prosjektene som positive. Samtidig kan det se ut som om prosjektene i liten grad trekkes med videre i undervisningen, og de kan på den måten sies å støtte opp om forståelsen av at UBUprosjekter er noe eksternt som hører til utenfor den ordinære undervisningen. For at disse prosjektene skal være med på å fremme et større fokus på UBU i skolen, må de i større grad integreres i undervisningen heller enn å være så «event-preget» som de kan synes å være i dag.

Det som imidlertid trekkes fram som en tydelig hemmer for å få til en mer helhetlig satsing på UBU, er fokuset på vurdering og testing som er i skolen i dag (Sinnes \& Eriksen, 2015). Lærerne kjenner seg stresset for å komme gjennom alle kompetansemålene. Elevene kjenner på presset om å oppnå gode karakterer og ser også på de tverrfaglige prosjektene som tidkrevende og noe som kommer utenom den ordinære undervisningen. Skoleeier peker på at de har fokusert på «Vurdering For Læring» heller enn på bærekraftig utvikling. Flere peker også på foreldrene som en hindring for økt satsing på tverrfaglige prosjekter fordi de presser på for at elevene skal oppnå læring i de teoretiske fagene og få gode karakterer. Intervjuene viser at det er et stort potensial for å utvikle arbeidsmåter og eksempler på prosjekter som integrerer et fokus på bærekraftig utvikling. Det er viktig at det blir tydelig for elever, foreldre, lærere og ledelse at UBU er en del av undervisningen som også vil støtte opp om sluttvurderingen i fagene ved å gi elevene en større forståelse om sammenhenger som også vil fremme relevansen av fagene.

Vi har i denne studien sett at alle informantene i skolene er positive til satsingen på bærekraftig utvikling i de nye læreplanene, men at ansvaret for utviklingen av et helhetlig UBU-fokus likevel kan pulveriseres så lenge alle «sitter på gjerdet» og venter på at andre aktører skal ta initiativ. Straume (2016) påpeker i en kritisk analyse av Norges satsing på UBU i forbindelse med FNs tiår, at selv om det ble laget en strategi for UBU, ble den aldri nedfelt i handlingsplaner eller kompetansemål for skolene. Den fikk dermed liten innvirkning på praksis i skolene. Implementering av en tverrfaglig satsing på bærekraftig utvikling i skolen må derfor nedfelles som konkrete læringsmål i de nye læreplanene. En forpliktende satsing på UBU krever også at skolen og lærerne får tid og rom til å utvikle organisasjonen og læringsmåter lokalt. Vi stiller spørsmål om satsingen på UBU i fagfornyelsen er tilstrekkelig for å utvikle den tverrfaglige forståelsen og handlingskompetansen som er nødvendig for å forberede elevene på å leve bærekraftige liv i framtiden.

Om forfatterne

Birgitte Bjønness er førsteamanuensis i realfagdidaktikk ved Norges miljø- og biovitenskapelige universitet (NMBU), hvor hun underviser i praktisk-pedagogisk utdanning og lektorprogrammet. Hennes forskning er knyttet til utforskende 
arbeidsmåter i naturfag, og hun arbeider med utdanning for bærekraftig utvikling både i lærerutdanningen og som forskningsfelt.

Institusjonstilhørighet: Fakultet for realfag og teknologi, Norges miljø- og biovitenskapelige universitet, Postboks 5003 NMBU, 1432 Ås.

Epost: birgitte.bjonness@nmbu.no

Astrid Tonette Sinnes er professor i realfagdidaktikk ved NMBU og har vært sentral i arbeidet med å utvikle denne lærerutdanningens fokus på bærekraftig utvikling. Hun har publisert innen feltet utdanning for bærekraftig utvikling, samt kjønn og realfag i både norsk og internasjonal sammenheng. Hun er forfatter av den første norske boken om utdanning for bærekraftig utvikling rettet mot lærerutdanningen: Utdanning for bcerekraftig utvikling: Hva, hvorfor og hvordan? (Universitetsforlaget).

Institusjonstilhørighet: Fakultet for realfag og teknologi, Norges miljø- og biovitenskapelige universitet, Postboks 5003 NMBU, 1432 Ås.

Epost: astrid.sinnes@nmbu.no

\section{Referanser}

Alsop, S. \& Bencze, L. (2014). Activism! Toward a more radical science and technology education. I L. Bencze \& S. Alsop (red.), Activist Science and Technology Education (s. 1-19). Springer.

Andresen, M. U., Høgmo, N. \& Sandås, A. (2015). Learning from ESD projects during the UN Decade in Norway. I R. Jucker \& R. Matar (red.), Schooling for Sustainable Development in Europe. Concepts, Policies and Educational Experiences at the End of the UN Decade of Education for Sustainable Development (s. 241-256). Dordrecht: Springer.

Braun, V. \& Clarke, V. (2006). Using thematic analysis in psychology. Qualitative research in psychology, 3(2), 77-101.

Breiting, S. \& Mogensen, F. (1999). Action competence and environmental education. Cambridge Journal of Education, 29(3), 349-353.

Burgess, J., Harrison, C. M. \& Filius, P. (1998). Environmental communication and the cultural politics of environmental citizenship. Environment and Planning 30, 1445-1460.

Gadotti, M. (2010). Reorienting education practices towards sustainability. Journal of Education for Sustainable Development, 4(2), 203-211.

Grønt flagg (2018). Nettsidene til grønt flagg. Lastet ned 28/8/2018 fra https://grontflagg.fee.no/

Hodson, D. (2014). Becoming part of the solution: Learning about activism, learning through activism, learning from activism. I L. Bencze \& S. Alsop (red.), Activist science and technology education (s. 67-98). Springer.

Jensen, B. B. (2002). Knowledge, Action and Pro-Environmental Behavior. Environmental Education Research, 8(3), 325-334.

Jensen, B. B. \& Schnack, K. (1997). The action competence approach in environmental education. Environmental education research, 3(2), 163-178.

Kirke- og undervisningsdepartementet (1974). Mønsterplan for grunnskolen. Oslo: Aschehoug. 
Koller, K. T. (2009). Uteskole = praksis + teori. En studie av muligheter og utfordringer med uteskole i naturfag på videregående trinn 1. Masteroppgave, Universitetet for miljø- og biovitenskap, Ås.

Kunnskapsdepartementet (2016). Fag - Fordypning - Forståelse. En fornyelse av Kunnskapsløftet. (Meld. St. 28, 2015-16). Oslo: Kunnskapsdepartementet.

Kvale, S. (2008). Doing interviews. Sage.

Laumann, K. (2007). The Missing Story - Education for Sustainable Development in Norway. Masteroppgave, Senter for Utvikling og miljø, Universitetet i Oslo.

Leo, U. \& Wickenberg, P. (2013). Professional norms in school leadership: Change efforts in implementation of education for sustainable development. Journal of Educational Change, 14(4), 403-422.

Leo, U. \& Wickenberg, P. (2015). Under one umbrella: Professional norms promoting education for sustainable development at the school level. I V. Simonovska \& P. Mannix McNamara (red.), Schools for Health and Sustainability - Theory, Research and Practice (s. 61-80). Springer.

McKeown, R. \& Hopkins, C. (2007). Moving beyond the EE and ESD disciplinary debate in formal education. Journal of Education for Sustainable Development, 1(1), 17-26.

Mogensen, F. \& Schnack, K. (2010). The action competence approach and the 'new'discourses of education for sustainable development, competence and quality criteria. Environmental education research, 16(1), 59-74.

Mogren, A., Gericke, N. \& Scherp, H.-Å. (2018). Whole school approaches to education for sustainable development: a model that links to school improvement. Environmental education research. doi: https://doi.org/10.1080/13504622.2018.1455074

Naturfagsenteret (2010). Læreplananalyse - utdanning for bærekraftig utvikling. Lastet ned 6/5/2019 fra http://www.natursekken.no/c1188058/artikkel/vis.html?tid=2090227

Natursekken (2018). Les mer om Den naturlige skolesekken. Lastet ned 28/8/2018 fra https://www.natursekken.no/c1187999/artikkel/vis.html?tid=2102111

Olsson, D., Gericke, N. \& Chang Rundgren, S.-N. (2016). The effect of implementation of education for sustainable development in Swedish compulsory schools - assessing pupils' sustainability consciousness. Environmental Education Research, 22(2), 176-202.

Scott, W. (2013). Developing the sustainable school: Thinking the issues through. Curriculum Journal, 24(2), 181-205.

Sinnes, A. T. \& Eriksen, C. C. (2015). Education for Sustainable Development and International Student Assessments: Governing Education in Times of Climate Change. Global Policy, 7(1), 46-55.

Sinnes, A. T. \& Straume, I. (2017). Bærekraftig utvikling, tverrfaglighet og dybdelæring; fra big ideas til store spørsmål. Acta Didactica, 11(3), Art. 7.

Sjaastad, J., Carlsten, T. C., Opheim, V. \& Jensen, F. (2014). Evaluering av Den naturlige skolesekken: Utdanning for bœrekraftig utvikling på ulike lœringsarenaer. NIFU-Rapport 38/2014. Oslo: Nordisk institutt for studier av innovasjon, forskning og utdanning.

Sterling, S. (2001). Sustainable Education: Re-Visioning Learning and Change. Schumacher Briefings: ERIC.

Straume, I. S. (2016). «Norge ligger på dette området langt fremme i forhold til de fleste land»: Utdanning for bærekraftig utvikling i Norge og Sverige. Nordisk tidsskrift for pedagogikk og kritikk, 2(3), 78-96.

Sundstrøm, E. (2016). Utdanning for bœrekraftig utvikling (UBU) fra et liererperspektiv. En studie av naturfaglereres perspektiv og undervisningspraksis av UBU. Masteroppgave, Norges Arktiske Universitet, Tromsø. 
UNESCO (2014). UNESCO Roadmap for Implementing the Global Action Programme on Education for Sustainable Development. Paris: United Nations Educational, Scientific and Cultural Organisation.

Utdanningsdirektoratet (2011). Generell del av lcereplanen. Hentet 17/6/2019 fra https://www.udir.no/laring-og-trivsel/lareplanverket/generell-del-av-lareplanen/

Utdanningsdirektoratet (2018). Lcereplaner for Kunnskapsløftet. Hentet 28/8/2018 fra https://www.udir.no/laring-og-trivsel/lareplanverket/fag/

Vibe, N. (2012). Spørsmål til Skole-Norge. Resultater og analyser fra Utdanningsdirektoratets spørreundersøkelse blant skoler og skoleeiere. NIFU-Rapport 5/2012. Oslo: Nordisk institutt for studier av innovasjon, forskning og utdanning.

Wals, A. E. \& Benavot, A. (2017). Can we meet the sustainability challenges? The role of education and lifelong learning. European Journal of Education, 52(4), 404-413. 